URL: http://ojs.unimal.ac.id/index.php/JEPU

\section{ANALISIS EFISIENSI KEUNTUNGAN USAHATANI PADI SAWAH DENGAN TEKNIK TANAM PINDAH DAN TEKNIK TANAM BENIH LANGSUNG DI KAMPUNG ALUE JANGAT KECAMATAN DARUL IHSAN KABUPATEN ACEH TIMUR}

\author{
Aminah ${ }^{* a}$ Devi Andriyani*b \\ *Fakultas Ekonomi dan Bisnis Universitas Malikussaleh \\ a Corresponding author: aminahnasir197@gmail.com \\ b deviandriyani@unimal.ac.id
}

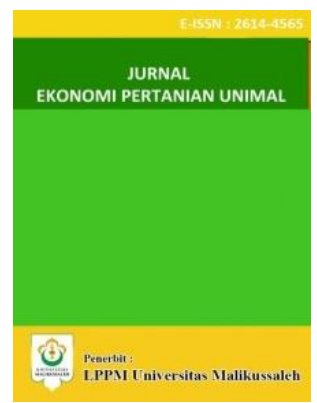

\begin{tabular}{l}
\hline A R T I C L E I N F O R M A T I O N \\
\hline Keywords: \\
Farming, Rice Farmers, Profits, \\
Capital, Labor, Planting \\
Period, TAPIN, TABELA, DEA, \\
Efficiency
\end{tabular}

Keywords:

Farming, Rice Farmers, Profits, Period, TAPIN, TABELA, DEA, Efficiency 
tanam serta keuntungan yang diperoleh oleh petani padi sawah dengan teknik TAPIN dan teknik TABELA di Kampung Alue Jangat Kecamatan Darul Ihsan Kabupaten Aceh Timur pada tabel 1.1 dibawah ini.

Tabel 1.1

Data Modal, Tenaga Kerja, Masa Tanam, Penerimaan dan Keuntungan Usahatani Padi Sawah dengan Teknik TAPIN dan Teknik TABELA di Kampung Alue Jangat Kecamatan Darul Ihsan Kabupaten Aceh Timur

\begin{tabular}{|c|c|c|c|c|c|c|c|}
\hline \multirow[b]{2}{*}{$\begin{array}{c}\text { Teknik } \\
\text { Tanam }\end{array}$} & \multirow[b]{2}{*}{$\begin{array}{c}\text { Luas } \\
\text { Lahan } \\
\left(\mathrm{m}^{2}\right)\end{array}$} & \multirow[b]{2}{*}{$\begin{array}{l}\text { Nama } \\
\text { Petani }\end{array}$} & \multicolumn{3}{|c|}{ Input } & \multicolumn{2}{|c|}{ Output } \\
\hline & & & $\begin{array}{l}\text { Modal } \\
\text { (Rp) }\end{array}$ & $\begin{array}{c}\text { Tenaga } \\
\text { Kerja } \\
\text { (Jiwa) }\end{array}$ & $\begin{array}{c}\text { Masa } \\
\text { Tanam } \\
\text { (Hari) }\end{array}$ & $\begin{array}{l}\text { Penerimaan } \\
\quad(\mathrm{Rp})\end{array}$ & $\begin{array}{c}\text { Keuntungan } \\
\text { (Rp) }\end{array}$ \\
\hline TAPIN & 2800 & Ti Sapiah & 1.342 .000 & 5 & 90 & 4.600 .000 & 3.258 .000 \\
\hline TAPIN & 3600 & Jauhari & 2.600 .000 & 10 & 90 & 5.750 .000 & 3.150 .000 \\
\hline TAPIN & 1200 & Rubiah & 784.000 & 8 & 90 & 3.450 .000 & 2.666 .000 \\
\hline TABELA & 3200 & Balqiah & 1.580 .000 & 6 & 100 & 6.900 .000 & 5.320 .000 \\
\hline TABELA & 1600 & Safriani & 800.000 & 5 & 100 & 2.300 .000 & 1.500 .000 \\
\hline TABELA & 4800 & Nurjannah & 3.660 .000 & 12 & 100 & 6.900 .000 & 3.240 .000 \\
\hline
\end{tabular}

Sumber: Hasil observasi peneliti, 2019

Berdasarkan tabel 1.1 diatas dapat dilihat perbedaan input maupun output yang digunakan dan dihasilkan oleh kedua teknik tanam padi sawah tersebut. Terlihat bahwa keuntungan terbesar diperoleh oleh usahatani milik Balqiah menggunakan TABELA yang memiliki luas lahan sebesar $3200 \mathrm{~m}^{2}$ mampu menghasilkan keuntungan sebesar Rp 5.320.000 dan penggunaan modal sebesar Rp 1.580.000 . Sedangkan usahatani padi sawah milik Jauhari dengan penguasaan luas lahan $>400 \mathrm{~m}^{2}$ dari Rubiah hanya mampu menghasilkan keuntungan sebesar Rp 3.150.000 dengan menggunakan teknik TAPIN.

Namun hal tersebut berbanding terbalik dengan yang terjadi pada usahatanipadi saawah milik Ti Sapiah dan Rubiah dengan teknik TAPIN serta usahatani padi sawah milik Safriani dan Nurjannah proses dengan TABELA. Ti Sapiah dengan penguasaan lahan seluas $2800 \mathrm{~m}^{2}$ mampu menghasilkan keuntungan sebesar Rp 3.258.000 sedangkan Nurjannah dengan penguasaan lahan seluas $4800 \mathrm{~m}^{2}$ hanya mampu menghasilkan keuntungan sebesar Rp 3.240.000.

Kemudian usahatani padi sawah yang menggunakan teknik TAPIN milik Rubiah mampu mengungguli usahatani padi sawah yang menggunakan teknik TABELA milik Safriani dengan perbedaan penguasaan lahan seluas $400 \mathrm{~m}^{2}$ lebih luas sawah Safriani.

Berdasarkan uraian latar belakang penelitian di atas, maka penulis tertarik untuk melakukan penelitian ini dengan judul "Analisis Efisiensi Keuntungan Usahatani Padi Sawah
Dengan Teknik Tanam Pindah dan Teknik Tanam Benih Langsung di Kampung Alue Jangat Kecamatan Darul Ihsan Kabupaten Aceh Timur".

\section{KAJIAN TEORITIS}

\section{Efesiensi}

Efisiensi ialah cara perusahaan dalam mengelola sumber keuangan, material, proses, peralatan, tenaga kerja maupun biaya secara efektif. (Sadikin, 2005)

Efisiensi adalah usaha mencapai prestasi yang sebesar-besarnya dengan mengunakan kemungkinankemungkinan yang tersedia (material, mesin, dan manusia) dalam tempo yang sependek-pendeknya, didalam keadaan yang nyata (sepanjang keadaan itu bisa berubah) tanpa mengganggu keseimbangan antara faktor-faktor tujuan, alat, tenaga dan waktu. Efisiensi adalah perbandingan terbaik antara suatu hasil dengan usahanya.

Efisiensi adalah salah kemampuan suatu usaha untuk menghasilkan suatu keluaran (output) tertentu dengan menggunakan sejumlah masukan (input) tentu secara optimal. Efisiensi dari suatu usaha memiliki kaitan yang erat antara masukan (input) yang digunakan dengan keluaran (output) yang dihasilkan. Variabel keluaran (output) pada usahatani yang sering digunakan adalah pendapatan dan hasil produksi. Variabel pendapatan diperoleh dari hasil perkalian antara produksi dengan harga jual produk. Variabel masukan (input) dilakukann dengan faktor produksi seperti pupuk, benih, tenaga kerja, lahan, gasi, menajemen, dll.

\section{UsahaTani Padi}

Menurut Soekartawi (2002), ilmu usahatani adalah ilmu yang dipelajari untuk memkasimlakan produksi dengan menggunakan sumber daya yang terbatas.

Usahatani adalah ilmu untuk mempelajari bagaimana tata cara pengelolaan proses produksi baik itu dari zat tanah, TK Teknolog dll secara dengan efektif, efisien dan berkelanjutan (Rahim dan Hastuti, 2007). Untuk dapat kita lihat proses kelanjutkan dari pertadian maka dapat digunakan dengan berbagai cara system yang dianggap akan menguntungkan,

\section{Konsep Pendapatan Usahatani}

Pendapatan usahatani akan menghitung selisih antara penerimaan dan pengeluaran (Soekartawi, 2006). Hubungan antara pendapatan, penerimaan dan biaya dapat ditulis dalam bentuk matematis sebagai berikut:

$$
\mathrm{Pd}=\mathrm{TR}-\mathrm{TC}
$$


Rumus untuk mengukur pendapatan dari usahatani adalah dengan menggunakan metode analisis R/C Rasio (Return Cost Rasio).

Secara teoritis apabila nilai dari R/C Rasio $=1$ artinya usahatani yang dijalankan dengan posisi yang tidak untung maupun tidak rugi atau BEP (Break Event Point). Nilai dari R/C Rasio < 1 artinya usahatani yang dijalankan berada pada kondisi yang merugikan dan tidak efisien. Nilai dari R/C Rasio > 1 artinya usaha tani yang dilakukan berada pada kondisi yang menguntungkan dan efisien.

\section{Faktor - Faktor yang Mempengaruhi Pendapatan Usahatani}

1. Faktor internal dan eksternal

Akan bersama-sama mempengaruhi biaya dan pendapatan usahatani. Dilihat dari faktor internal diantaranya ialah umur, semakin tua lebih banyak pengalamana sehingga akan lebih baik usahanya. Faktor eksternal terbagi dua yaitu dilihat dari segi faktor produksi (input) dan dari segi produksi (ouput).

2. Faktor manajemen

Petani harus mampu meminimalisir biata namun memikirkan untuk mendapatkan keuntungan yang besar.

\section{Usahatani Padi dengan Sistem Tanam Pindah (TAPIN) dan Tanam Benih Langsung (TABELA)}

TAPIN adalah proses penanaman padi di sawah dengan persemaian dan selajutnya dipidahkan ke lahan sebenarnya. TABELA proses ini banyak unggulnya, seperti mempersingkat masa panenya, sehingga akan meningkatakn jumlah waktu tanam pertahunnya dan mengurnagi anggaran untuk pembiayaan TK. TABELA bisa digunakan untuk agroekositem yang memeiliki irigasi,wadah penampungan hujan dan lahan pasang surut (Zarwazi et al., 2015).

\section{Pengukuran Efisiensi}

Pengukuran efisiensi dapat dilakukan melalui tiga pendekatan yaitu:

1. Pendekatan rasio

Diukur dengan pnedekata ouput dan input yang dgunakan:

$$
\text { Efisiensi }=\frac{\text { output }}{\text { Input }}
$$

\section{Pendekatan regresi}

Pendekatan ini dalam mengukur efisiensi menggunakan sebuah model dari tingkat output tertentu sebagai fungsi dari berbagai tingkat input tertentu. Fungsinya dapat disajikan sebagai berikut:

$$
\mathrm{Y}=\mathrm{f}\left(\mathrm{X}_{1}, \mathrm{X}_{2}, \mathrm{X}_{3}, \mathrm{X}_{4} \ldots \ldots \mathrm{X}_{\mathrm{n}}\right)
$$

\section{Pendekatan frontier}

Menurut Silkman (1986) dalam Ario (2005), proses ini dibedakan menjadi, yaitu pendekatan frontier parametrik dan non parametrik.

\section{Metode Data Envelopment Analysis (DEA)}

Muharam \& Pusvitasari (2007) menjelaskan DEA adalah sebuah metode optimasi program matematika yang mengukur efisiensi teknik suatu unit kegiatan ekonomi (UKE)/Decision Making Unit (DMU) dan membandingkan secara relatif terhadap DMU yang lain.

Tujuan dari metode DEA adalah untuk mengukur tingkat efisiensi dari DMU (unit pengambilan keputusan / DMUs) terhadap DMU sejenis pada saat semua unit berada dibawah kurva efisien frointer-nya. DMU adalah unit yang akan dianalisa menggunakan metode DEA penyebutan unit untuk diiteliti tersebut yaitu berupa perusahaan, instansi atau organisasi kemudian ada objek yang dilibatkan dalam menggunakan alat analisis ini yaitu proses pengeluaran dan penerimaan dari setiap DMU yang akan di teliti.

\section{Kerangka Konseptual}

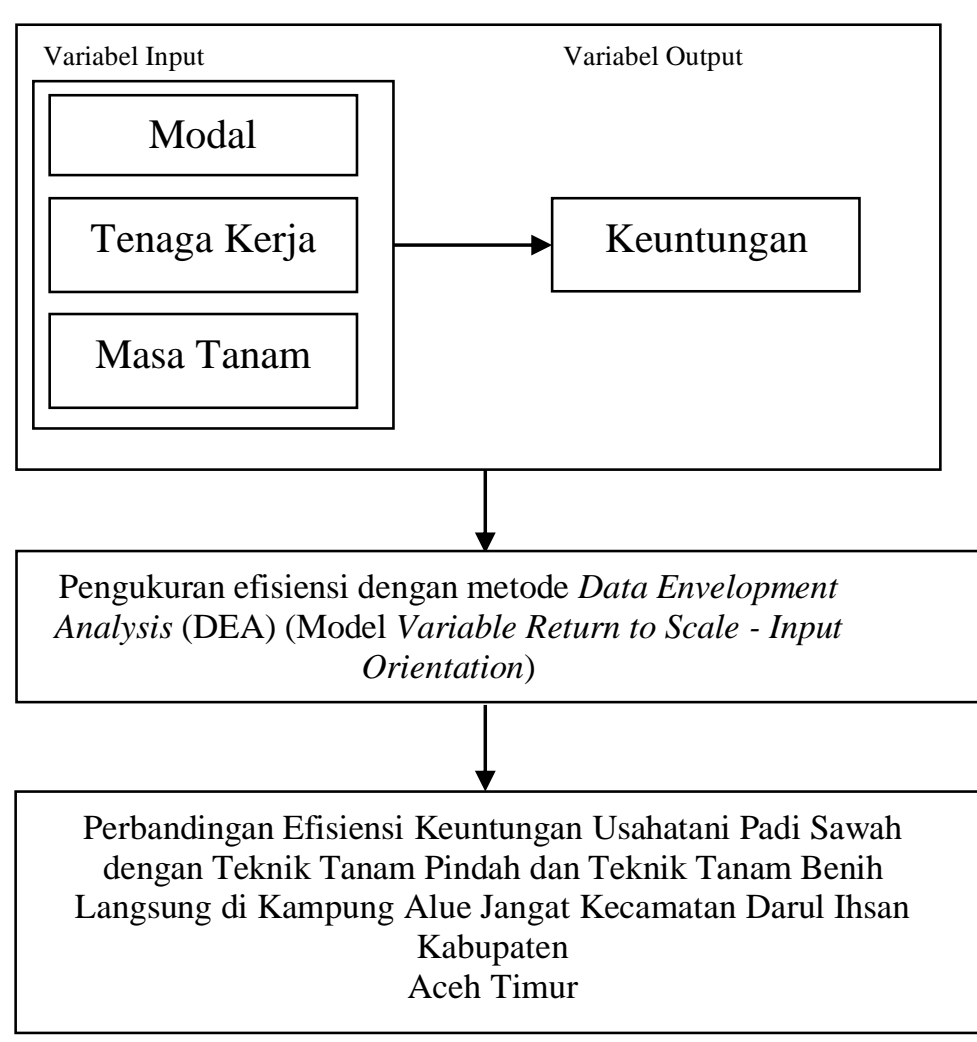

Gambar 2.1 Kerangka Konseptual 


\section{Hipotesis}

$\mathrm{H}_{0}$ : Diduga modal, tenaga kerja, dan masa tanamtidak efisien dalam menghasilkan output keuntungan usahatani padi dengan teknik tanam pindah dan teknik tanam benih langsung di Kampung Alue Jangat.

$\mathrm{H}_{\mathrm{a}}$ : Diduga modal, tenaga kerja, dan masa tanam efisien dalam menghasilkan output keuntungan usahatani padi dengan teknik tanam pindah dan teknik tanam benih langsung di Kampung Alue Jangat

\section{METODE PENELITIAN}

\section{Objek dan Lokasi Penelitian}

Objeknya ialah perbedaan efisiensi modal, tenaga kerja, masa tanam terhadap keuntungan para usahatani dengan proses TAPIN dan teknik TABELA dan yang menjadi lokasi penelitiannya adalah Desa Alue Jangat Kecamatan Darul Ihsan Kabupaten Aceh Timur.

\section{Jenis da Sumber Data}

Data yang digunakan data primer, dari yang didapatkan langsung dilapangan. Sedangkan sumbernya dari observasi peneliti melalui kuisioner dengan petani padi sawah yang menggunakan teknik tanam pindah dan tanam langsung.

\section{Sampel dan Populasi}

Populasi dalam penelitian ini adalah seluruh petani yang menanam padi dengan sistem tabur benih langsung dan juga yang menanam padi dengan sistem tanam pindah yang ada di Kecamatan Darul Ihsan Kecamatan Aceh Timur yaitu sebanyak petani 395 jiwa. (Kantor Geuchik, 2019).

Sampel digunakan teknik simple random sampling. Oleh karenanya dapat mengambil sampel sebanyak $15 \%$ dari jumlah populasi sehingga jumlah sampelnya adalah $15 \%$ × $395=$ 60 petani.

Dengan demikian peneliti menggenapkan jumlah sampel yaitu menjadi 60 orang dengan pembagian sebanyak 30 petani dengan metode TAPIN dan 30 petani dengan teknik TABELA

\section{Definisi Operasional Variabel}

1. Modal adalah adalah jumlah biaya pengeluaran awal atau masa tanam yang dinyatakan dalam satuan rupiah dan menjadi input pertama.

2. TK adalah jumlah total manusia yang dipekerjakan oleh petanipadi swah pada semua proses penanaman padi sawah hingga pemanenan yang dinyatakan dalam satuan jiwa dan menjadi input kedua.

3. Masa tanam adalah jangka waktu yang digunakan oleh suatu usahatani padi sawah dari mulai penanaman hingga masa panen yang dinyatakan dalam satuan hari dan menjadi input ketiga.

4. Keuntungan merupakan imbalan didapatkan dari masing-masing teknik yang dinyatakan dengan satuan rupiah sebagai output.

\section{Metode Analisis data}

Penelitian ini menggunakan metode Data Envelopment Analysis (DEA) yaitu proses tata cara untuk mengevaluasi dan memecahkan masalah dengan mengabungkan nilai outpt dan input.

Oleh karenanya, adapun asumsi atau model yang digunakan Variable Return to Scale (VRS) yang berorientasikan pada input yaitu bertujuan untuk meminimalkan input untuk mencapai nilai skala yang efisien sesuai dengan output yang telah dihasilkan.

\section{Pengujian Efisiensi Menggunakan Pendekatan Variable Return to Scale (VRS)}

Asumsinya bahwa rasio antara penambahan input dan output tidak sama (variable return to scale). Hasil model ini menambahkan kondisi convexity bagi nilai-nilai bobot $\lambda$, dengan memasukkan dalam model batasan berikut:

$$
\sum_{j=1}^{n} \lambda j=1
$$

Selanjutnya model BCC dapat ditulis dengan persamaan berikut: $\lambda$

Max $\pi$ (Efisiensi DMU Model VRS)

Subject to:

$\sum_{j=1}^{n} x i j \quad \lambda i j \geq \pi i o$

$\sum_{j=1}^{n} y r j \quad \lambda j \geq y i o$

$\sum_{j=1}^{n} \lambda j \geq 1$

$\sum_{j=1}^{n} \lambda j \geq 0$

Dimana:

$\pi=$ Efisiensi DMU Model VRS

$\mathrm{n} \quad=$ Jumlah DMU

$\mathrm{m} \quad=$ Jumlah Input

$\mathrm{s} \quad=$ Jumlah Output

$x i j \quad=$ Jumlah Input ke-i DMU $\mathrm{j}$

$y r j \quad=$ Jumlah Output ke- $\mathrm{r}$ DMU $\mathrm{j}$

$\lambda j \quad=$ Bobot DMU j untuk DMU yang dihitung 
4. HASIL PENELITIAN DAN PEMBAHASAN

Hasil Pengolahan data Variable Return to Scale (VRS) - Output Oriented Petani TAPIN Desa Alue Jangat

Tabel 4.1

Hasil Perhitungan Technical Efficiency DEA Petani TAPIN Desa Alue Jangat dengan Pendekatan VRS Berorientasi Output

\begin{tabular}{|c|c|c|}
\hline No & Nama Petani & \multicolumn{2}{|c|}{$\begin{array}{c}\text { Nilai Efisiensi } \\
\text { DEA }\end{array}$} \\
\hline 1 & Abdul Gani & 0,806 \\
\hline 2 & M.Nur & 1,000 \\
\hline 3 & Marwan & 0,546 \\
\hline 4 & Ilyas & 0,905 \\
\hline 5 & Marwan Hs & 1,000 \\
\hline
\end{tabular}

Sumber: Hasil olah data, 2019

Berdasarkan tabel 4.1 petani TAPIN di Desa Alue Jangat dengan nilai efisiensi sebesar sama dengan satu (=1) hanya petani M.Nur dan Marwan Hs. Responden berada pada garis frontier, dengan kata lain laba yang didapat telah efisien.

Sedangkan petani TAPIN Abdul Gani, Marwan, dan Ilyas masing-masing memperoleh nilai 0,806 , 0,546, dan 0,905 . Yang artinya keuntungan petani ini belum efisien berdasarkan output yang telah dihasilkan karena nilai efisiensi kurang dari satu $(<1)$.

Hasil Pengolahan Data Variable Return to Scale (VRS) - Output Oriented Petani TABELA Desa Alue Jangat

Tabel 4.2

Hasil Perhitungan Technical Efficiency DEA Petani TABELA Desa Alue Jangat dengan Pendekatan VRS Berorientasi Output

\begin{tabular}{|c|c|r|}
\hline No & Nama Petani & \multicolumn{2}{|c|}{$\begin{array}{c}\text { Nilai Efisiensi } \\
\text { DEA }\end{array}$} \\
\hline 1 & Mustafa & 1,000 \\
\hline 2 & T. Raman & 1,000 \\
\hline 3 & Mansiah & 0,636 \\
\hline 4 & Abdul Rasyip & 1,000 \\
\hline 5 & Liah & 1,000 \\
\hline
\end{tabular}

Sumber: Hasil olah data, 2019

Berdasarkan tabel 4.2 Petani dengan teknik tanam TABELA di Desa Alue Jangat yang menjadi sampel dalam penelitian ini yang memperoleh nilai efisiensi sama dengan satu $(=1)$ ialah Mustafa, T. Raman, Abdul Rasyip dan Liah. Dimana nilai 1.000 menunjukkkan bahwa responden berada pada garis frontier, dengan kata lain keuntungan yang diperoleh telah efisien.
Sedangkan petani TABELA Mansiah memperoleh nilai efisiensi kurang dari satu $(<1)$ yaitu masing-masing sebesar 0,636 . Hal ini berarti petani TABELA tersebut belum memperoleh keuntungan yang efisien berdasarkan output yang telah dihasilkan.

Dari kesepuluh petani dengan dua teknik tanam padi sawah yang berbeda tersebut, setelah dihitung dengan pendekatan VRS yang berorientasi pada output terlihat bahwa jumlah petani yang paling banyak memperoleh nilai efisien sama dengan satu $(=1)$ adalah petani dengan teknik tanam benih langsung (TABELA) yaitu berjumlah 4 petani dari total 5 sampel petani TABEELA. Sedangkan petani dengan teknik tanam pindah (TAPIN) yang memperoleh nilai efisien sama dengan satu $(=1)$ hanya sebanyak 2 petani dari total 5 sampel petani TAPIN.

\section{Pembahasan}

\section{Tingkat efisiensi Petani TAPIN di Desa Alue Jangat}

Berdasarkan hasil pengujian yang telah dilakukan dapat dilihat pada tabel 4.1 bahwa petani TAPIN di Desa Alue Jangat yang memperoleh nilai efisiensi sama dengan satu $(=1)$ berjumlah empat petani yaitu M.Nur, Ilyas, dan Marwan Hs. Hal ini berarti keuntungan yang diperoleh oleh keempat petani tersebut telah efisien. Sedangkan petani TAPIN Abdul Gani, Marwan dan Ilyas yang memperoleh nilai efisiensi sebesar 0,806, 0,546, dan 0,905 atau sama dengan bernilai di bawah satu $(<1)$ yang berarti bahwa keuntungan yang diperoleh belum efisien.

Dari tabel 4.3, tabel 4.4, dan tabel 4.5 tingkat inefisiensi petani TAPIN Abdul Gani, Marwan dan Ilyas berdasarkan masing-masing variabel input dan output yang digunakan dalam usaha tani padi sawah.

Tabel 4.3

Nilai Original, Target, Radial Movement dan Slack Movement Input Output Petani Abdul Gani yang Inefisiensi

\begin{tabular}{|l|ccccc|}
\hline \multicolumn{1}{|c|}{ Variabel } & $\begin{array}{c}\text { Nilai } \\
\text { Efisiensi }\end{array}$ & $\begin{array}{c}\text { Original } \\
\text { value }\end{array}$ & $\begin{array}{c}\text { Target } \\
\text { value }\end{array}$ & $\begin{array}{c}\text { Radial } \\
\text { movement }\end{array}$ & $\begin{array}{c}\text { Slack } \\
\text { movement }\end{array}$ \\
\hline & 0,806 & & & & \\
\hline $\begin{array}{l}\text { Output } \\
\begin{array}{l}\text { Keuntungan } \\
\text { Rp) }\end{array}\end{array}$ & 4.515 .000 & 5.600 .000 & 1.085 .000 & 0 \\
\hline Input & & & & 1.085 .000 \\
\hline $\begin{array}{l}\text { Modal } \\
\text { Rp) } \\
\begin{array}{l}\text { Tenaga Kerja } \\
\text { (Jiwa) }\end{array}\end{array}$ & 2.385 .000 & 1.300 .000 & 0 & -4 \\
$\begin{array}{l}\text { Masa Tanam } \\
\text { (Hari) }\end{array}$ & 8 & 4 & 0 & 0 \\
\hline
\end{tabular}

Sumber : Hasil olah data, 2019

Pada tabel 4.3 Petani Abdul Gani masih dapat menambah keuntungannya, hal in terlihat dari original value (nilai asli) yaitu sebesar Rp 4.515.000 < target value (nilai target) yaitu sebesar Rp 5.600.000 dengan selisih sebesar $\mathrm{Rp} 1.085 .000$ atau sama dengan 
meningkat sebesar 24,03\%. Guna mengefisienkan keuntungan yang dapat diperoleh, petani Abdul Gani dapat mengefisienkan penggunaan input yang belum efisien yaitu modal dan penggunaan jumlah tenaga kerja.

Pada variabel input modal terlihat bahwa nilai asli > nilai target dimana nilai target sebesar Rp 1.300.000 sedangkan nilai original sebesar Rp 2.385.000. Maka untuk mengefisienkan keuntungan petani Abdul Gani dapat mengurangi penggunaan modal sebesar Rp 1.085.000.

Kemudian pada variabel tenaga kerja juga memperoleh nilai target sedikit rendha dibanding dengan nilai asli yang telah digunakan dimana nilai target sebanyak 4 jiwa sedangkan tenaga kerja yang digunakan oleh petani Abdul Gani adalah 8 jiwa sehingga untuk lebih mengefisienkan keuntungan maka petani Marwan TK harus dikurang sebanyak 4 jiwa atau orang.

\section{Tabel 4.4}

Nilai Original, Target, Radial Movement dan Slack Movement Input Output Petani Marwan yang Inefisiensi

\begin{tabular}{|c|c|c|c|c|c|}
\hline Variabel & $\begin{array}{l}\text { Nilai } \\
\text { Efisie } \\
\text { nsi }\end{array}$ & $\begin{array}{l}\text { Original } \\
\text { value }\end{array}$ & $\begin{array}{l}\text { Target } \\
\text { value }\end{array}$ & $\begin{array}{l}\text { Radial } \\
\text { movement }\end{array}$ & $\begin{array}{l}\text { Slack } \\
\text { movement }\end{array}$ \\
\hline & \multicolumn{5}{|l|}{0,546} \\
\hline \multicolumn{6}{|l|}{ Output } \\
\hline $\begin{array}{l}\text { Keuntungan } \\
\text { (Rp) }\end{array}$ & & $\begin{array}{l}3.060 .00 \\
0\end{array}$ & 5.600 .000 & 2.540 .000 & 0 \\
\hline \multicolumn{6}{|l|}{ Input } \\
\hline $\begin{array}{l}\text { Modal } \\
\text { (Rp) }\end{array}$ & & $\begin{array}{l}1.540 .00 \\
0\end{array}$ & 1.300 .000 & 0 & -240.000 \\
\hline $\begin{array}{l}\text { Tenaga } \quad \text { Kerja } \\
\text { (Jiwa) }\end{array}$ & & 6 & 4 & 0 & -2 \\
\hline $\begin{array}{ll}\text { Masa } & \text { Tanam } \\
\text { (Hari) } & \end{array}$ & & 90 & 90 & 0 & 0 \\
\hline
\end{tabular}

Sumber : Hasil olah data, 2019

Berdasarkan tabel 4.4 terlihat bahwa petani Marwan masih dapat menambah keuntungannya, dari original value (nilai asli) yang lebih kecil dari target value (nilai target) yaitu dengan selisih sebesar Rp 2.540.000. Guna mengefisienkan keuntungan yang dapat diperoleh, petani Marwan dapat mengefisienkan penggunaan input yang belum efisien yaitu modal dan penggunaan jumlah tenaga kerja.

Pada variabel input modal terlihat bahwa nilai asli lebih tinggi dari nilai target dimana nilai target sebesar Rp 1.300.000 sedangkan nilai original sebesar $\mathrm{Rp}$ 1.540.000. Maka untuk mengefisienkan keuntungan petani Marwan dapat mengurangi penggunaan modal sebesar Rp 240.000.

Kemudian pada variabel tenaga kerja juga memperoleh nilai target yang lebih rendah dibanding dengan nilai asli yang telah digunakan dimana nilai target sebanyak 4 jiwa sedangkan tenaga kerja yang digunakan oleh petani Marwan adalah 6 jiwa sehingga untuk lebih mengefisienkan keuntungan maka petani Marwan harus mengurangi tenaga kerja sebanyak 2 jiwa atau orang.

Tabel 4.5

\section{Nilai Original, Target, Radial Movement dan Slack Movement Input Output Petani Ilyas yang} Inefisiensi

\begin{tabular}{|c|c|c|c|c|c|}
\hline Variabel & $\begin{array}{l}\text { Nilai } \\
\text { Efisiensi }\end{array}$ & $\begin{array}{l}\text { Origin } \\
\text { al } \\
\text { value }\end{array}$ & $\begin{array}{l}\text { Target } \\
\text { value }\end{array}$ & $\begin{array}{l}\text { Radial } \\
\text { movemen } \\
t\end{array}$ & $\begin{array}{l}\text { Slack } \\
\text { moveme } \\
\text { nt }\end{array}$ \\
\hline & \multicolumn{5}{|l|}{0,905} \\
\hline \multicolumn{6}{|l|}{ Output } \\
\hline $\begin{array}{l}\text { Keuntungan } \\
(\mathrm{Rp})\end{array}$ & & $\begin{array}{l}5.070 .0 \\
00\end{array}$ & $\begin{array}{l}5.600 .0 \\
00 \\
\end{array}$ & 530.000 & 0 \\
\hline \multicolumn{6}{|l|}{ Input } \\
\hline $\begin{array}{l}\text { Modal } \\
\text { (Rp) }\end{array}$ & & $\begin{array}{l}1.830 .0 \\
00\end{array}$ & $\begin{array}{l}1.300 .0 \\
00\end{array}$ & 0 & $-\overline{530.000}$ \\
\hline $\begin{array}{l}\text { Tenaga Kerja } \\
\text { (Jiwa) }\end{array}$ & & 8 & 4 & 0 & -4 \\
\hline $\begin{array}{l}\text { Masa Tanam } \\
\text { (Hari) }\end{array}$ & & 90 & 90 & 0 & 0 \\
\hline
\end{tabular}

Sumber : Hasil olah data, 2019

Pada tabel 4.5 petani Ilyas masih dapat menambah keuntungannya, dari original value (nilai asli) yaitu sebesar Rp 5.070.000 < target value (nilai target) yaitu sebesar Rp 5.600.000 dengan selisih sebesar Rp 530.000 atau serupa meningkat 10,45\%. Guna mengefisienkan keuntungan yang dapat diperoleh, petani Ilyas dapat mengefisienkan dalam kegiatan gunanya belum efisien yaitu modal dan penggunaan jumlah tenaga kerja.

Pada variabel input modal terlihat bahwa nilai asli > nilai target dimana nilai target sebesar $\mathrm{Rp}$ 1.300.000 sedangkan nilai original sebesar Rp 1.830.000. Maka untuk mengefisienkan keuntungan petani Ilyas dapat diturunkan modal sebesar $\mathrm{Rp}$ 530.000 .

Kemudian pada variabel tenaga kerja juga memperoleh nilai target yang lebih rendah dibanding dengan nilai asli yang telah digunakan dimana nilai target sebanyak 4 jiwa sedangkan tenaga kerja yang digunakan oleh petani Ilyas adalah 8 jiwa sehingga untuk lebih mengefisienkan keuntungan maka petani Ilyas tk kerja dikurangkan sebanyak 4 jiwa atau orang.

\section{Tingkat Efisiensi Petani TABELA di Desa Alue Jangat}

Berdasarkan hasil pengujian pada tabel 4.2 bahwa sebanyak eempat (4) petani TABELA di Desa Alue Jangat pada penelitian ini memperoleh nilai efisiensi =1 yaitu petani Mustafa, T.Raman, Abdul Rasyip dan Liah. Artinya petani dengan teknik tanam padi sawah TABELA di dalam penelitian ini telah mengefisiensikan keuntungan yang diperoleh berdasarkan pada input yang telah digunakan. 
Sedangkan petani TABELA Mansiah memperoleh nilai efisiensi kurang dari satu $(<1)$ yaitu sebesar 0,636 yang berarti bahwa petani TABELA tersebut belum memperoleh keuntungan yang efisien.

Berikut dapat dilihat pada tabel 4.7 tingkat inefisiensi petani Mansiah, berdasarkan masingmasing variabel input dan output yang digunakan dalam usaha tani padi sawah dengan teknik tanam TABELA.

Tabel 4.6

Nilai Original, Target, Radial Movement dan Slack Movement Input Output Petani Mansiah yang Inefisiensi

\begin{tabular}{|l|lllll|}
\hline Variabel & $\begin{array}{l}\text { Nilai } \\
\text { Efisie } \\
\text { nsi }\end{array}$ & $\begin{array}{l}\text { Origina } \\
\text { l value }\end{array}$ & $\begin{array}{l}\text { Target } \\
\text { value }\end{array}$ & $\begin{array}{l}\text { Radial } \\
\text { movemen } \\
t\end{array}$ & $\begin{array}{l}\text { Slack } \\
\text { movement }\end{array}$ \\
\hline & 0,636 & & & \\
\hline $\begin{array}{l}\text { Output } \\
\text { Keuntunga } \\
\text { (Rp) }\end{array}$ & 3.140 .0 & $\begin{array}{l}4.934 .00 \\
0\end{array}$ & $\begin{array}{l}1.794 .00 \\
0\end{array}$ & 0 \\
\hline Input & 00 & 0 & & 0 \\
\hline $\begin{array}{l}\text { Modal } \\
\text { (Rp) }\end{array}$ & & 1.460 .0 & 1.460 .00 & 0 & $-0,2$ \\
$\begin{array}{l}\text { Tenaga } \\
\text { Kerja } \\
\text { (Jiwa) }\end{array}$ & 00 & 0 & & 0 \\
$\begin{array}{l}\text { Masa } \\
\text { Tanam } \\
\text { (Hari) }\end{array}$ & 5 & $4,8 \approx 5$ & 0 & 0 \\
\hline
\end{tabular}

Sumber : Hasil olah data, 2019

Berdasarkan pada tabel 4.6 di atas dapat terlihat bahwa petani Mansiah masih dapat menambah keuntungannya, hal in terlihat dari original value (nilai asli) yaitu sebesar $\mathrm{Rp}$ $3.140 .000<$ target value (nilai target) yaitu sebesar Rp 4.934.000 dengan selisih sebesar Rp $1.794 .000=$ meningkat sebesar $57,13 \%$ dengan menggunakan input yang tetap.

\section{PENUTUP}

\section{Kesimpulan}

Berdasarkan ini penulis melalui peroleh data dari Kantor Geuchik dan hasil olahan data dengan regresi linier berganda maka dapat diambil beberapa kesimpulan sebagai berikut:

Berdasarkan hasil olah data dengan metode Data Envelopment Analysis (DEA) menggunakan pendekatan Variable Return to Scale (VRS) dengan berorientasikan pada output, dari kesepuluh petani dengan dua teknik tanam padi sawah yang berbeda tersebut terlihat bahwa teknik tanam padi sawah dengan jumlah petani yang paling banyak memperoleh nilai efisien sama dengan satu $(=1)$ adalah petani dengan teknik tanam benih langsung (TABELA) yaitu berjumlah 4 petani dari total 5 sampel petani TABELA. Sedangkan petani dengan teknik tanam pindah
(TAPIN) yang memperoleh nilai efisien sama dengan satu $(=1)$ hanya sebanyak 2 petani dari total 5 sampel petani TAPIN.

Kemudian petani dengan teknik tanam TABELA di Desa Alue Jangat yang menjadi sampel dalam penelitian ini yang memperoleh nilai efisiensi sama dengan satu (=1) ialah Mustafa, T. Raman, Abdul Rasyip dan Liah. Dimana nilai 1.000 menunjukkkan bahwa responden berada pada garis frontier, dengan kata lain keuntungan yang diperoleh telah efisien. Sedangkan petani TABELA Mansiah memperoleh nilai efisiensi kurang dari satu $(<1)$ yaitu sebesar 0,636. Hal ini berarti petani TABELA tersebut belum memperoleh keuntungan yang efisien berdasarkan output yang telah dihasilkan.

\section{Saran}

Adapun beberapa saran-saran yang diharapkan penulis dalam penelitian ini adalah sebagai berikut:

Petani - petani padi sawah yang memperoleh nilai efisiensi kurang dari satu $(<1)$ seperti petani Abdul Gani, Marwan, Ilyas, dan Mansiah maka dapat memaksimalkan keuntungan yang diperoleh dengan cara dan solusi yang telah dipaparkan pada bagian pembahasan.

Pengurangan jumlah tenaga kerja dapat diiringi dengan penambahan teknologi dan mesin guna meningkatkan produktivitas padi sawah untuk mencapai nilai skala yang efisien. Selain menambah produktivitas padi, mesin juga dapat mengurangi penggunaan modal dalam jangka panjang

\section{DAFTAR PUSTAKA}

Anggraeni, M. (2017). Analisis Pengaruh Pengeluaran Pemerintah di Sektor Pendidikan, Kesehatan dan pertanian Terhadap Pertumbuhan Ekonomi Indonesia Periode 1970-2015. Jurnal Pendididkan Dan Ekonomi, Volume 6(Nomor 5).

Anonymous. (2010). Slide Testing dan Implementasi Sistem. Palembang: Maxikom.

Bumulo, F. (2009). Peran APBD Terhadap Pertumbuhan Ekonoi Daerah. Jurnal Legalitas, Vol 2(No.1).

Hardjowigeno. (2005). Ilmu Tanah. Jakarta: Akademika Presindo.

Indranada. (2003). Pengelolaan Kesuburan Tanah. Jakarta: PT. Bina Aksara.

Manoi, C. S. (2015). Pengaruh Pengeluaran Pemerintah Terhadap PDRB Sektor Pertanian di Provinsi Sulawesi Utara. Jurnal, Volume 3(Nomor 2).

Panggabean, S, M. (2010). Posisi Pertanian Dalam Teori Pembangunan Ekonomi Rostow dan Lewis. Bogor: Ghalia Indonesia.

Subri. (2013). Ekonomi Sumber Daya Manusia. (P. R. 
G. Persada, Ed.). Jakarta.

Sugiyono. (2009). Metode Penelitian Bisnis. Bandung: Alfabeta.

Sukirman, S. (2009). Perkerasan Lentur Jalan Raya. Bandung: Nova.

Sukirno, S. (2006). Pengantar Teori Makro. Jakarta: PT. Graha Grafindo.

Suwanti. (2013). Analisis Pengaruh Pengeluaran untuk sektor pertanian terhdapa PDRB Sektor Pertanian 35 Kabupaten/Kota di Provinsi Jawa Tengah Tahun 2007-2010. Journal of Economics, Vol 2(Nomor 4 ISSN 23373814).

Yulianita, A. (2009). Analisis Sektor Unggulan dan Pengeluaran Pemerintah di Kabupaten Ogan Komering Ilir. Universitas Sriwijaya. 